\title{
SMOKING PREVENTION AMONG YOUTH
}

\section{PREVENCIJA UPOTREBE DUVANA MEĐU MLADIMA}

\author{
Biljana Kilibarda ${ }^{1}$, Dejana Vuković ${ }^{2}$
}

${ }^{1}$ Institut za javno zdravlje Srbije "Dr Milan Jovanović Batut", Beograd, Srbija

${ }^{2}$ Univerzitet u Beogradu, Medicinski fakultet, Institut za socijalnu medicinu, Beograd, Srbija

Correspondence: kilibarda_b@yahoo.com

\section{Abstract}

For majority of smokers, onset of smoking occurs during adolescence, period of intensive growth and development, and this early smoking initiation is associated with many adverse health effects. Smoking prevention measures include not only prevention of onset, but also prevention of transition from experimentation to chronic tobacco use and dependence and smoking cessation. Effective preventive measures should be based on relevant theory and scientific evidence on behavior determinants. In this review article, we present evidence from researches on effectiveness of school programs, community-based programs, media campaigns and stress the importance of considering new challenges in tobacco control and

Keywords:

tobacco use, prevention, youth other promising strategies, as well as the need for early detection of nicotine dependence signs among adolescents. In practice, many preventive measures are not based on theory and some interventions can be contra productive. Regardless of type of intervention and setting in which is implemented, it is of importance to take into account context for its implementation.

\section{Sažetak}

Najveći procenat pušača počinje da puši tokom perioda adolescencije, kada rast i razvoj nisu još uvek kompletno završeni. Zavisnost od nikotina se može razviti u kratkom roku od otpočinjanja pušenja, a pušenje tokom adolescencije povezano je sa mnogobrojnim posledicama po zdravlje. Preventivne mere usmerene su ne samo na sprečavanje otpočinjanja konzumiranja već i na sprečavanje da oni koji već eksperimentišu sa duvanom razviju zavisnost, kao i na odvikavanje od pušenja. Kako bi bile efektivne, preventivne intervencije treba da budu zasnovane na teorijskim okvirima i dokazima i naučnim saznanjima o determinantama ponašanja. U radu su prikazani dokazi iz istraživanja o efektivnosti školskih programa, programa u zajednici, medijskih kampanja, uz ukazivanje na potrebu sagledavanja novih mogućnosti i izazova u kontroli duvana, kao što je rano otkrivanje zavisnosti od nikotina kod ado-

Ključne reči: upotreba duvana, prevencija, mladi lescenata. Dokazi pokazuju da mnoge preventivne intervencije nisu zasnovane na teorijskom konceptu, kao i da pojedine intervencije mogu biti i kontraproduktivne. Bez obzira na vrstu i okruženje u kome se preventivne intervencije sprovode, važno je uzeti u obzir kontekst $\mathrm{u}$ kojem će intervencije biti sprovedene.
Kilibarda B. et al. MedPodml 2020, 71(3):42-48

(c)

The authors declare no conflicts of interest. doi: $10.5937 / \mathrm{mp} 71-28273$

Editorial board: podmladak.med.bg@gmail.com 
Uvod

Upotreba duvana spada u vodeće preventabilne faktore rizika i povezana je sa osam miliona prevremenih smrtnih slučajeva u svetu godišnje $(1,2)$. Zavisnost od nikotina, koji spada u psihoaktivne supstance (PAS), prepoznata je u X međunarodnoj klasifikaciji bolesti, povreda i uzroka smrti Svetske zdravstvene organizacije (SZO) pod dijagnozom F17 (duševni poremećaji i poremećaji ponašanja uzrokovani upotrebom duvana), a farmakološki i bihevioralni procesi koji određuju zavisnost od nikotina slični su procesima kod zavisnosti od ilegalnih droga (3). U svetu puši $21 \%$ odrasle populacije (4), a prema podacima Globalnog istraživanja upotrebe duvana kod mladih, sprovedenih od 2012. do 2015. godine, prevalencija pušenja kod učenika 13-15 godina starosti iznosi 10,7\%, sa velikim varijacijama među državama (5). Podaci istraživanja sprovedenog prema istoj metodologiji pokazuju da u Srbiji puši $11 \%$ učenika ove starosne grupe (6).

Najveći procenat pušača počinje da puši tokom adolescencije, kada rast i razvoj nisu još uvek kompletno završeni i kada je podložnost štetnim efektima duvana veća (3). Pored toga, rane epidemiološke studije o štetnosti pušenja ukazale su da za većinu hroničnih bolesti izazvanih pušenjem rizik raste sa dužinom pušačkog staža $(3,7,8)$, a rano otpočinjanje pušenja povezano je i sa većom verovatnoćom nikotinske zavisnosti $(9,10)$. Neurotoksični efekti nikotina su najizraženiji tokom rane adolescencije, tokom koje se razvijaju procesi razvoja inhibicione kontrole (11), a, usled nedovršenog razvoja mozga, nikotin može negativno da utiče na normalan tok sazrevanja mozga i ima dugoročne posledice na kognitivne sposobnosti i mentalno zdravlje $(3,12,13)$. Iz navedenih razloga, mladi predstavljaju ključnu ciljnu grupu u prevenciji upotrebe duvana.

\section{Klasifikacija prevencije}

Prema klasifikaciji koja proističe iz predloga Komisije za hronične bolesti (14), prevencija se deli na primarnu, koja ima za cilj smanjenje pojave novih slučajeva, sekundarnu, kojom se teži ranom otkrivanju i smanjenju progresije bolesti, kao i na kasnije definisanu tercijarnu, koja ima za cilj smanjenje posledica i opterećenja usled postojećih oboljenja. Pored ova tri oblika prevencije, u kategorizaciju je uključena i primordijalna prevencija, termin predložen krajem sedamdesetih godina XX veka (15), koja podrazumeva preveniranje razvoja faktora rizika (npr. usvajanjem zakona o zabrani pušenja) (16), a u literaturi se razmatra i kvaternarni vid prevencije (17).

Podela prevencije na primarnu, sekundaru i tercijarnu podrazumeva razumevanje mehanizama koji povezuju uzrok bolesti sa pojavom bolesti. Od vremena kada je ovaj sistem razvijen brojna istraživanja su ukazala na složenost interakcije bioloških, psiholoških i socijalnih ili biopsihosocijalnih faktora u razvoju i ispoljavanju bolesti, uključujući i bolesti zavisnosti. U skladu sa novijim shvatanjima uticaja brojnih faktora rizika i njihove interakcije, u oblasti prevencije zloupotrebe psihoaktivnih supstanci, u koje spada i nikotin, od polovine XX veka u širokoj upotrebi je klasifikacija prevencije predložena od strane Instituta za medicinu iz SAD (18), bazirana na Gordonovoj klasifikaciji prevencije na univerzalnu, selektivnu i indikovanu prevenciju (19). U okviru ovog pristupa, ciljne grupe se razlikuju prema nivou rizika u vezi sa upotrebom supstanci, a intervencije se dizajniraju na osnovu nivoa rizika ciljne grupe. Univerzalna prevencija je usmerena na opštu populaciju, tj. ciljna grupa se ne razlikuje prema riziku, selektivna prevencija je usmerena ka grupama za koje se na osnovu postojanja bioloških, psiholoških, socijalnih faktora rizika smatra da su pod povećanim rizikom, dok je indikovana prevencija fokusirana na visokorizične pojedince, npr. pojedince koji su već eksperimentisali i imaju probleme, ali ne ispunjavaju dijagnostičke kriterijume za zavisnost. Od velikog značaja za smanjenje upotrebe duvana su strategije okruženja koje podrazumevaju šire mere kao što su oporezivanje, ograničenja za prodaju duvana i zabrane pušenja na određenim mestima. Ove strategije usmerene su na menjanje neposrednog kulturnog, socijalnog, psihološkog i ekonomskog okruženja u kome ljudi žive.

\section{Prevencija upotrebe duvana}

Prema definiciji Okvirne konvencije o kontroli duvana (OKKD) Svetske zdravstvene organizacije, kontrola duvana podrazumeva niz strategija smanjenja ponude i tražnje duvanskih proizvoda, kao i štetnih posledica njihove upotrebe, koje imaju za cilj očuvanje i unapređenje zdravlja stanovništva tako što će se eliminisati ili smanjiti potrošnja duvanskih proizvoda i izlaganje duvanskom dimu (20). Član 12. OKKD odnosi se na edukacije i upozoravanje stanovništva i drugih ciljnih grupa o štetnosti duvana i povezanim zdravstvenim, ekonomskim i ekološkim posledicama, uključujući i zavisnost od upotrebe duvana i izlaganja duvanskom dimu.

Prevencija u oblasti zloupotrebe psihoaktivnih supstanci (PAS), uključujući prevenciju upotrebe duvana, sklop je psiholoških, socijalnih, pravnih i zdravstvenih aktivnosti sa ciljem sprečavanja oštećenja zdravlja, nastanka bolesti i posledica korišćenja ovih supstanci. Kako bi bile efektivne, preventivne intervencije treba da budu zasnovane na dokazima i potrebno je sprovoditi ih pre, ali i nakon pojave simptoma/ponašanja jer su poremećaji povezani sa upotrebom duvana hronični i recidivirajući po svojoj prirodi.

\section{Faktori rizika i protektivni faktori povezani sa upotrebom duvana}

Polazna osnova u planiranju preventivnih intervencija je razumevanje faktora rizika i protektivnih faktora. Svako ponašanje, uključujući i rizično ponašanje kao što je upotreba duvana, pod uticajem je faktora koji se mogu svrstati u pet različitih domena, a to su: individualni, interpersonalni, institucionalni, tj. organizacioni (npr. politika 
protiv pušenja na radnom mestu ili u školi), zajednica i javna politika (21), a preventivne intervencije se mogu sprovoditi na različitim nivoima koji odgovaraju ovim domenima. Neki faktori, kao što je namera otpočinjanja pušenja, smatraju se proksimalnim i imaju direktni uticaj, a neki, kao što su socijalne norme, distalni su ili predisponirajući. Uticaj dodatnih faktora, poput stila roditeljstva tokom odrastanja ili cena cigareta, može zavisiti od drugih faktora kao što su ekonomski status ili osobine ličnosti. Brojna istraživanja ističu da višestruki faktori koji utiču na ponašanje predstavljaju dinamički sistem koji se menja sa razvojem ljudi i novim iskustvima u vezi sa određenim ponašanjem, a značaj ovih faktora varira u različitim razvojnim fazama čoveka. Određeni faktori, kao što su stil roditeljstva i vršnjaci, posebno su značajni tokom detinjstva i rane adolescencije, društveni i normativni procesi postaju značajniji tokom adolescencije, dok samoefikasnost postaje sve značajnija sa sticanjem iskustva i veština u oblasti društvenog ponašanja (22). Ipak, treba imati na umu i da izloženost faktorima rizika ne dovodi uvek do upotrebe supstanci ili eskalaciji upotrebe (23).

\section{Ciljevi, razvoj i oblici preventivnih intervencija}

Ciljevi preventivnih intervencija u vezi sa upotrebom duvana mogu biti sprečavanje otpočinjanja konzumiranja, odlaganje konzumiranja, sprečavanje razvijanja zavisnosti kod osoba koje već eksperimentišu sa duvanom, kao i odvikavanje od pušenja (23).

Jačanje napora na prevenciji upotrebe duvana otpočelo je ranih sedamdesetih godina XX veka, uporedo sa jačanjem pokreta za promociju zdravlja i shvatanjem da upotreba duvana izaziva zavisnost i druga oboljenja. Razvijene su mnogobrojne preventivne intervencije i implementirane od stane istraživača, privatnih kompanija i pojedinaca, a većina tih ranih intervencija polazila je od pretpostavke da deca, ukoliko budu znala da je pušenje štetno, to neće raditi. Rezultati evaluacije su pokazali da su ovakve intervencije uticale na znanje i stavove, ali nisu prevenirale otpočinjanje pušenja (24). U izveštaju rukovodioca javnog zdravlja SAD iz 1994. godine, pripremljenom od strane eksperata na osnovu velikog broja istraživanja, potvrđuje se da raniji pristupi koji su zasnovani na informisanju nisu efektivni u prevenciji upotrebe duvana kod mladih, dok pristupi koji uključuju razvoj socijalnih veština i upravljanja svojim ponašanjem deluju kao obećavajuće strategije (22).

Prevencija zavisnosti od upotrebe duvana i drugih adiktivnih ponašanja može biti teorijski podržana na tri nivoa i to u pogledu sadržaja, metodologije i implementacije u praksi (25). Neki od kognitivno bihevioralnih modela i teorija koji su se pokazali efektivnim u planiranju preventivnih intervencija kod adolescenata su: Model zdravstvenih uverenja (engl. Health Belief Model), Teorija planiranog ponašanja (engl. Theory of Planned Behaviour), Teorija razložne akcije (engl. Theory of Reasoned Action) i Transteoretski model (engl. Transtheoretical Model) $(21,26,27)$. Ključni elementi ovih teorija uključuju znanje o zdravstvenim rizicima, percepciju podložnosti posledicama i njihovoj ozbiljnosti, samoefikasnost, ciljeve i motivaciju, kao i barijere i faktore koji olakšavaju promene ponašanja. Dokazi, ipak, pokazuju da u praksi mnoge preventivne intervencije nisu zasnovane na nekom teorijskom konceptu (28), kao i da da pojedine intervencije mogu biti i kontraproduktivne.

Preventivne intervencije se mogu podeliti i prema mestu, tj. okruženju u kome se implementiraju: intervencije u obrazovnim ustanovama, intervencije usmerene na porodicu, zdravstvene ustanove, zajednicu, šire okruženje i medijske kampanje.

Intervencije za prevenciju upotrebe duvana u školama

Intervencije za prevenciju upotrebe duvana u školama i debate o njima su u fokusu brojnih stručnjaka u prethodne tri decenije. Njihova glavna percipirana prednost je veliki obuhvat dece i to što se edukacija uklapa u svakodnevne aktivnosti i delatnost škole, a primenjuje se više tipova intervencija baziranih na različitim teorijskim modelima.

Pored intervencija zasnovanih samo na informisanju, na čiju neefektivnost su istraživači ukazali još osamdesetih godina XX veka (29), sprovode se i druge intervencije, kao što su normativne edukacije koje polaze od toga da veliki broj adolescenata precenjuje rasprostranjenost pušenja i vidi pušenje kao uobičajeno ponašanje, a česte su i intervencije usmerene na jačanje veština za odupiranje društvenom pritisku, odnosno programi i kurikulumi bazirani na Bandurinoj teoriji socijalnog učenja (30) i socijalno kognitivnoj teoriji (31) koji imaju za cilj jačanje socijalnih kompetencija kao što su rešavanje problema, donošenje odluka, odupiranje interpersonalnim i medijskim pritiscima, jačanje samokontrole, samopouzdanja i odgovora na stresne situacije. Česta je i kombinacija različitih kurikuluma i širih inicijativa u okviru i van škole, uključujući intervencije za roditelje, intervencije u zajednici i inicijative za politiku o upotrebi duvana na nivou škole i na nivou šire zajednice (takse, dostupnost, reklame). U izveštaju iz 2012. godine rukovodilac javnog zdravlja SAD zaključuje da postoji dovoljan broj dokaza da školski programi mogu imati pozitivne kratkoročne efekte i smanjiti prevalenciju pušenja među učenicima kada su bazirani na dokazima o efektivnosti (3), a njihovu efektivnost potvrđuju i druga istraživanja (32). Uprkos brojnim istraživanjima, podaci o tome šta je najefektivnije i dalje su nekonzistentni. Studija iz 2018. godine pokazuje da je među evaluiranim intervencijama samo nekoliko, zasnovanih na hipotezi da će znanje i socijalne veštine prevenirati pušenje, bilo delimično efektivno, te da ove intervencije mogu dovesti do povećanja znanja, ali da nisu uticale na smanjenje stope pušenja (33).

Sistematski pregled literature iz 2015. godine na osnovu 50 randomizovanih kontrolisanih istraživanja efekata školskih intervencija pokazao je da su najefektivnijie one koje kombinuju socijalne kompetencije i socijalne 
uticaje. Isti pregled literature potvrdio je ranije nalaze da programi zasnovani na informisanju i samo na socijalnim uticajima nisu efektivni za mlade uzrasta 5-18 godina koji nisu nikada pušili (34). Analiza efektivnosti preventivnih intervencija namenjenih devojčicama je pokazala da kombinovanje školskih programa sa medijskom kampanjom ima veću verovatnoću uspešnosti, ali i da su potrebna dalja istraživanja kako bi se ovo potvrdilo (35).

Uprkos postojanju nekonzistentnih rezultata o efektivnosti, dovoljan je broj dokaza koji pokazuju da je za efektivnost školskih intervencija potrebno da budu sveobuhvatne, interaktivne, da otpočnu u ranom uzrastu, da uključuju adekvatan broj časova, kao i da budu integrisane u šire pristupe kontroli duvana u zajednici (36). Slabiji efekti ili potpuno odsustvo efekata ovih intervencija mogu poticati od neadekvatne implementacije, ali i neadekvatnog i/ili nedovoljnog trajanja treninga za edukatore (37). Novi školski programi treba da obuhvate i nove izazove u kontroli duvana, a, kako bi se povećala verovatnoća uspešnosti, treba da budu i specifični za grupe pod povećanim rizikom, kao i da ih sprovode obučeni edukatori (38). Istraživanja ističu da je značajno razmotriti da li su nastavnici najbolji izbor za implementatore preventivnih intervencija, pre svega zbog otpora koji neki nastavnici imaju prema sopstvenom učešću, a i zbog činjenice da neki od nastavnika koji bi implementirali program puše (39). Od značaja za uspešnu implementaciju ovih intervencija je i iskustvo nastavnika koji sprovode program (49).

Posebna pažnja u prevenciji posvećuje se intervencijama zasnovanim na vršnjačkoj edukaciji, koja podrazumeva da ih sprovode vršnjaci, tj. osobe slične po demografskim (godine života ili pol), profesionalnim ili po nekim drugim karakteristikama kao što je nivo rizika za određena rizična ponašanja. Vršnjačka edukacija obuhvata aktivnosti usmerene na prosvećivanje, edukaciju i podsticanje željenih oblika ponašanja među pripadnicima grupe sa kojom dele karakteristike, a sprovodi se formalno, u struktuiranom okruženju ili neformalno, tokom svakodnevne interakcije. Zasnovana je na bihevioralnim teorijama povezanim sa zdravstvenim ponašanjem (41), a popularnost u promociji zdravlja među mladima joj je u porastu od devedesetih godina XX veka (42). Ove intervencije se mogu implementirati u različitim sredinama, a dokazi o njihovoj efektivnosti u prevenciji upotrebe duvana postoje već duži niz godina (43-45). Dizajniranje ovih intervencija zahteva, međutim, pažljivo i adekvatno planiranje, obuku, nadzor i evaluaciju. Značajni faktori u vršnjačkoj edukaciji su motivacija i povezanost edukatora sa ciljnom grupom intervencije (46).

\section{Intervencije usmerene na porodicu}

Pored intervencija u obrazovnim ustanovama, posebnu grupu čine porodične edukacije i programi. Sistematski pregled literature, koji je uključio 22 studije randomizovanih kontrolisanih intervencija, heterogenih $\mathrm{u}$ odnosu na komponente programa, a namenjenih roditeljima, pokazao je da ove intervencije mogu pozitivno da utiču na sprečavanje otpočinjanja pušenja kod dece i adolescenata, kao i da su dokazi o efektivnosti najsnažniji za programe visokog intenziteta koji se primenjuju nezavisno od školskih intervencija. Autori ovog pregleda literature ukazuju da su efektivne intervencije one koje su usmerene na izgradnju stilova roditeljstva koji podrazumevaju snažno interesovanje za decu i adolescente, sa jasnim pravilima ponašanja, ali ne u smislu autoritativnog roditeljskog stila (46).

\section{Prevencija upotrebe duvana i odvikavanje od} pušenja u zdravstvenim ustanovama

Brojna istraživanja ukazuju na potrebu uključivanja intervencija $u$ vezi sa duvanom u zdravstvene ustanove i ukazuju na značajnu ulogu koju pedijatri mogu imati u prevenciji upotrebe duvana kod adolescenata i njihovih roditelja $(48,49)$. Iako se brojne intervencije $\mathrm{u}$ prevenciji upotrebe duvana sprovode u mnogim zdravstvenim ustanovama, studije i dokazi o njihovoj efektivnosti i dalje su ograničeni (50).

Poseban značaj imaju programi za odvikavanje od pušenja adolescenata. Dugi niz godina smatralo se da se nikotinska zavisnost razvija tek nakon određenog perioda svakodnevnog i redovnog pušenja (51), međutim, sve veći broj istraživanja ukazuje da se zavisnost od nikotina može razviti u kratkom periodu nakon otpočinjanja pušenja i pre nego što adolescent postane svakodnevni pušač, što ukazuje da je period u kome treba prevenirati razvoj zavisnosti nakon eksperimentisanja kraći nego što se ranije mislilo (52-54). Iz navedenih razloga, $\mathrm{u}$ cilju preveniranja razvoja zavisnosti neophodne su intervencije usmerene na mlade koji već puše, ne samo svakodnevno već i povremeno. Zavisnost i odvikavanje adolescenata od pušenja ima svoje specifičnosti i neke od terapija prvog izbora za odrasle pušače nisu adekvatne za mlade ili nisu evaluirane $(55,56)$. S obzirom na to da veliki procenat adolescenata već ima znake zavisnosti i želi da prestane da puši, ove intervencije je neophodno sprovoditi i nikako se ne smeju zanemariti (57). Skrining adolescenata na prisustvo ranih znakova zavisnosti od duvana važan je i nedovoljno korišćen alat u prevenciji dugotrajnog pušenja (9) i neophodno je iznalaženje načina za njegovu implementaciju u praksu.

\section{Programi u zajednici}

Sveobuhvatne intervencije u zajednici značajne su u promociji zdravlja, a bolje razumevanje interakcije i kombinovanih efekata društvenih, kulturnih i drugih faktora iz okruženja iniciralo je njihovo sprovođenje (58). Mobilizacija zajednice ima za cilj promenu društvenih normi i svesti o potrebi i značaju različitih mera kontrole duvana, a bazirana je na tri ključna koncepta: društvenom kapitalu, osnaživanju i socijalnim promenama $(41,59)$. Intervencije u zajednici u vezi sa duvanom imaju više komponenti i podrazumevaju korišćenje re sursa na nivou zajednice u cilju uticaja na individualno ponašanje i na društvene norme u zajednici, a njihova efektivnost kod mladih je potvrđena brojnim dokazima 
(3). Primeri multikomponentnih programa u zajednici su intervencije koje se implementiraju u školama, ali uključuju i roditelje i medije i organizacione komponente u zajednici. Zbog razlika u regulativima na nivou zajednice potrebna su dodatna istraživanja kojima bi se utvrdio doprinos tih regulativa u ukupnoj efektivnosti multikomponentnih intervencija u zajednici (60).

\section{Medijske kampanje}

Veliku primenu u prevenciji pušenja imaju i medijske kampanje. Dobro planirane i sprovedene medijske kampanje imaju uticaj na proces donošenja odluka na individualnom nivou koji treba da ojača namere pojedinaca da promene ponašanje i time povećaju verovatnoću usvajanja željenog zdravstvenog ponašanja. Kampanje deluju i indirektno tako što podstiču interpersonalnu komunikaciju na nivou užeg i šireg okruženja koja može dovesti do promena društvenih normi (61-63). Brojna istraživanja potvrđuju efektivnost medijskih kampanja u prevenciji pušenja i podsticanju pušača da prestanu da puše $(3,64)$, ali je potrebno u obzir uzeti i razlike u dizajnu, okruženju, trajanju, sadržaju i intenzitetu intervencija, metodi evaluacije i pokazateljima (65). Istraživanja ukazuju da su efektivne kampanje one sa dužim trajanjem (najmanje tri godine), većeg intenziteta, kao i da uspešnosti kampanje doprinosi kombinovanje sa aktivnostima u školama, kao i korišćenje različitih medija, ali zbog razlika u dizajnu kampanja i evaluacije ove rezultate treba interpretirati sa predostrožnošću (66). Intenzivne kampanje koje se fokusiraju na razotkrivanje manipulativnih metoda duvanske industrije i efekte pasivnog pušenja veoma verovatno smanjuju konzumiranje cigareta i imaju pozitivan efekat na denormalizaciju pušenja, dok strategije pretežno bazirane na isticanju kratkoročnih i dugoročnih štetnih efekata po zdravlje imaju manji potencijal (67).

Neophodno je uzeti u obzir metodološka ograničenja studija iz kojih potiču dokazi o efektivnosti, kao i razlike u karakteristikama kampanja. Kampanje koje su dovele do pozitivnih promena zasnovane su na određenim teorijskim konceptima, formativnim istraživanjima i adekvatnom in tenzitetu i trajanju $(63,68)$. Faktori koji mogu dovesti do neefektivnosti medijskih kampanja uprkos njihovom potencijalu za diseminaciju poruka su, između ostalog, upotreba neadekvatnih formata, nedovoljna izloženost porukama, fokusiranje na promene ponašanja za koje ciljna grupa nema kapacitet (61), kao i kampanje čije sprovođenje nije praćeno dodatnim intervencijama (60).

\section{Ostale intervencije za prevenciju upotrebe duvana}

Neke preventivne intervencije su dostupne i putem interneta i mogu privući adolescente interaktivnim pristupom, a rezultati istraživanja ukazuju da ove intervencije mogu biti efektivne $(69,70)$. Pored interaktivnih online in tervencija, pojavljuju se i druge intervencije čija efektivnost treba dodatno da bude potvrđena istraživanjima, a tu spadaju i one u kojima se koriste podsticaji, tj. određene nagrade za učesnike (71).U mnogim zemljama implementiraju se i programi zasnovani na zastrašivanju, što se nije pokazalo efikasnim već je, suprotno očekivanim efektima, dovelo do odbrambenih reakcija umesto pozitivne promene ponašanja (72). U neefektivne intervencije spadaju i one kojima se implicira da je pušenje ponašanje koje je karakteristično za odrasle. Ovakve intervencije su bile finansirane od strane duvanske industrije sa ciljem lobiranja protiv uvođenja efektivnih legislativnih mera i ograničenja reklamiranja širom sveta (73).

\section{Zaključak}

Bez obzira na vrstu i okruženje u kome se sprovode, efektivne preventivne intervencije zasnovane su na teorijskim okvirima i naučnim dokazima o determinantama ponašanja, uz povezivanje intervencija sa ciljevima ponašanja i uzimanja u obzir konteksta u kome će intervencije biti sprovedene (74). Pažljivo planiranje je značajno jer „bez jasnih opštih i specifičnih ciljeva postoji opasan rizik sprovođenja preventivnog rada radi sebe samog, umesto u korist ciljne populacije" (75).

Neophodno je naglasiti da veliki broj evaluiranih preventivnih intervencija potiče iz razvijenih zemalja, pa to treba imati u vidu prilikom tumačenja rezultata, a pri planiranju i implementaciji intervencija moraju se uzeti u obzir socioekonomski i kulturalni kontekst (76). Javnozdravstveni stručnjaci sve više se fokusiraju na razumevanje zašto neke intervencije u jednoj sredini deluju, a u drugoj ne. Važni elementi svih preventivnih intervencija su procena potreba, razvoj, praćenje implementacije i procena njegove efikasnosti $(77,78,68)$.

\section{Literatura}

1. WHO. WHO Report on the Global Tobacco Epidemic 2019 World Health Organization: Geneva; 2019.

2. WHO. WHO Report on the Global Tobacco Epidemic, 2008: The MPOWER Package. World Health Organization: Geneva; 2008.

3. National Center for Chronic Disease Prevention and Health Promotion (US) Office on Smoking and Health. Preventing Tobacco Use Among Youth and Young Adults: A Report of the Surgeon General. Atlanta (GA): Centers for Disease Control and Prevention (US); 2012. Available from: https://www.ncbi nlm.nih.gov/books/NBK99237/

4. Reitsma MB, Fullman N, Ng M, Salama JS, Abajobir A, Abate $\mathrm{KH}$, et al. Smoking prevalence and attributable disease burden in 195 countries and territories, 1990-2015: a systematic analysis from the Global Burden of Disease Study 2015. The Lancet. 2017. 389(10082): p. 1885-1906.

5. Arrazola RA, Pun E, De Quevedo GI, Babb S, Armour BS. Current Tobacco Smoking and Desire to Quit Smoking Among Students Aged 13-15 Years - Global Youth Tobacco Survey, 61 Countries, 2012-2015. MMWR Morb Mortal Wkly Rep. 2017(66): p. 533-537.

6. Kilibarda B, Nikolic N, Krstev S, Sovic N, Gudelj Rakic J. Globalno istrazivanje upotrebe duvana kod mladih 13-15 godina u Srbiji 2017. godine. Institut za javno zdravlje Srbije: 2018.

7. Doll R, R Peto. Cigarette smoking and bronchial carcinoma: dose and time relationships among regular smokers and lifelong non-smokers. Journal of epidemiology and community health.1978;32(4): p. 303-313. 
8. Peto R. Influence of dose and duration of smoking on lung cancer rates. IARC Sci Publ. 1986(74); p. 23-33.

9. Dierker L, Hedeker D, Rose J, Selya A, Mermelstein R. Early emerging nicotine dependence symptoms in adolescence predict daily smoking in young adulthood. Drug Alcohol Depend. 2015;151:267-271. doi:10.1016/j.drugalcdep.2015.03.009

10. Doubeni CA, Reed G, Difranza JR. Early course of nicotine dependence in adolescent smokers. Pediatrics. 2010;125(6):1127-1133. doi:10.1542/peds.2009-0238

11. DeBry SC, Tiffany ST. Tobacco-induced neurotoxicity of adolescent cognitive development (TINACD): a proposed model for the development of impulsivity in nicotine dependence. Nicotine Tob Res. 2008;10(1):11-25. doi:10.1080/14622200701767811

12. Brown RA, Lewinsohn PM, Seeley JR, Wagner EF. Cigarette smoking, major depression, and other psychiatric disorders among adolescents. J Am Acad Child Adolesc Psychiatry. 1996;35(12):16021610. doi:10.1097/00004583-199612000-00011

13. Deas D. Adolescent substance abuse and psychiatric comorbidities. J Clin Psychiatry. 2006; 67 Suppl 7:18-23.

14. Leavell H, Clark E. Preventive medicine for the doctor in his community an epidemiologic approach. 1 st edition, New York: McGraw-Hill; 1958

15. Strasser T. Reflections on cardiovascular diseases. Interdisciplinary science reviews. 1978. 3(3): p. 225-230.

16. Weintraub WS, Daniels SR, Burke LE, Franklin BA, Goff DC, Hayman LL, et al. Value of primordial and primary prevention for cardiovascular disease: a policy statement from the American Heart Association. Circulation. 2011;124(8):967-990. doi:10.1161/ CIR.0b013e3182285a81

17. Pandve HT. Quaternary prevention: need of the hour. Journal of family medicine and primary care. 2014. 3(4): p. 309-310.

18. Mrazek PJ, Haggerty RJ. Reducing risks for mental disorders: frontiers for preventive intervention research. Washington, DC: National Academy Press; 1994

19. Gordon RS. An Operational Classification of Disease Prevention. Public Health Reports. 1983; 98(2): p. 107-109.

20. WHO. WHO Framework Convention on Tobacco Control 2003 updated reprint 2004, 2005 Available from:http://apps.who.int/iris/ bitstream/10665/42811/1/9241591013.pdf?ua=1.

21. Sharma M. Theoretical foundations of health education and health promotion. Jones \& Bartlett Publishers: 2016

22. Elders MJ, Perry CL, Eriksen MP, Giovino GA. The report of the Surgeon General: preventing tobacco use among young people. Am J Public Health. 1994;84(4):543-547. doi:10.2105/ajph.84.4.543

23. Medina-Mora ME. Prevention of substance abuse: a brief overview. World Psychiatry. 2005; 4(1): p. 25-30.

24. Sussman S. Risk factors for and prevention of tobacco use. Pediatric Blood \& Cancer, 2005; 44(7): p. 614-619.

25. Pentz M A. Evidence-Based Prevention: Characteristics, Impact, and Future Direction. Journal of Psychoactive Drugs. 2003; 35(sup1): p. 143-152.

26. Glanz K, Rimer BK, Viswanath K. Health behavior: Theory, research, and practice. John Wiley \& Sons: 2015

27. Prochaska J O. Johnson S and Lee P. The transtheoretical model of behavior change. 2009.

28. Bartholomew E LK. Kay. Planning health promotion programs: an intervention mapping approach. San Francisco: Jossey-Bass:2006

29. Durell J, Bukoski W. Preventing substance abuse: the state of the art. Public Health Rep. 1984;99(1):23-31.

30. Bandura A. Social learning theory. Englewood Cliffs, N.J: Prentice Hall:1977

31. Bandura A. Social foundations of thought and action: A social cognitive theory. Social foundations of thought and action: A social cognitive theory. Englewood Cliffs, NJ, US. Prentice-Hall, Inc: 1986; xiii, 617-xiii, 617.

32. Wiehe SE, Garrison MM, Christakis DA, Ebel BE, Rivara FP. A systematic review of school-based smoking prevention trials with long-term follow-up. J Adolesc Health. 2005;36(3):162-169. doi:10.1016/j.jadohealth.2004.12.003

33. Nishio A, Saito J, Tomokawa S, Kobayashi J, Makino Y, Akiyama $\mathrm{T}$. et al. Systematic review of school tobacco prevention programs in African countries from 2000 to 2016. PLoS One. 2018;13(2):e0192489. Published 2018 Feb 6. doi:10.1371/journal.pone.0192489

34. Thomas R E, McLellan J and Perera R. Effectiveness of school-based smoking prevention curricula: systematic review and meta-analysis. BMJ Open. 2015. 5(3): p. e006976.

35. De Kleijn MJ, Farmer MM, Booth M, Motala A, Smith A, Sherman $S$ et al. Systematic review of school-based interventions to prevent smoking for girls. Syst Rev. 2015;4:109. Published 2015 Aug 14. doi:10.1186/s13643-015-0082-7

36. National Center for Chronic Disease Prevention and Health Promotion (US) Office on Smoking and Health. Efforts to Prevent and Reduce Tobacco Use Among Young People. In: Preventing Tobacco Use Among Youth and Young Adults: A Report of the Surgeon General. Atlanta (GA): Centers for Disease Control and Prevention (US); 2012.

37. Gingiss PM, Roberts-Gray C, Boerm M. Bridge-it: a system for predicting implementation fidelity for school-based tobacco prevention programs. Prev Sci. 2006;7(2):197-207. doi:10.1007/ s11121-006-0038-1

38. Sherman EJ and Primack BA. What works to prevent adolescent smoking? A systematic review of the National Cancer Institute's Research-Tested Intervention Programs. The Journal of school health. 2009. 79(9): p. 391-399.

39. Luna-Adame M, Carrasco-Giménez TJ and Rueda-García MdM. Evaluation of the effectiveness of a smoking prevention program based on the 'Life Skills Training' approach. Health Education Research. 2013. 28(4): p. 673-682.

40. Dusenbury L, Brannigan R, Hansen WB, Walsh J, Falco M. Quality of implementation: developing measures crucial to understanding the diffusion of preventive interventions. Health Educ Res. 2005;20(3):308-313. doi:10.1093/her/cyg134

41. Golechha M. Health Promotion Methods for Smoking Prevention and Cessation: A Comprehensive Review of Effectiveness and the Way Forward. Int J Prev Med. 2016;7:7. Published 2016 Jan 11. doi:10.4103/2008-7802.173797

42. Backett-Milburn K, Wilson S. Understanding peer education: insights from a process evaluation. Health Educ Res. 2000;15(1):85-96. doi:10.1093/her/15.1.85

43. Clarke JH, MacPherson B, Holmes DR, Jones R. Reducing adolescent smoking: a comparison of peer-led, teacher-led, and expert interventions. The Journal of School Health. 1986 Mar;56(3):102-106. DOI: 10.1111/j.1746-1561.1986.tb05707.x.

44. Black DR, Tobler NS and Sciacca J.P. Peer helping/involvement: an efficacious way to meet the challenge of reducing alcohol, tobacco, and other drug use among youth? J Sch Health. 1998. 68(3): p. 87-93.

45. Bilgiç N. and T. Günay. Evaluation of effectiveness of peer education on smoking behavior among high school students. Saudi medical journal, 2018. 39(1): p. 74-80.

46. Abdi F. and Simbar M. The Peer Education Approach in Adolescents- Narrative Review Article. Iranian journal of public health. 2013. 42(11): p. 1200-1206.

47. Thomas RE, Baker PRA, Thomas BC, Lorenzetti DL. Family $\bigotimes$ based programmes for preventing smoking by children and adolescents. Cochrane Database of Systematic Reviews 2015, Issue 2. Art. No.: CD004493. DOI: 10.1002/14651858. CD004493.pub3.

48. Harvey J, Chadi N and Canadian Paediatric Society, Adolescent Health Committee. Preventing smoking in children and adolescents: Recommendations for practice and policy. Paediatr Child Health. 2016;21(4):209-221. doi:10.1093/pch/21.4.209

49. Pbert L, Farber H, Horn K, lando HA, Muramoto M, O'Laughin et al. State-of-the-art office-based interventions to eliminate youth tobacco use: the past decade. Pediatrics. 2015;135(4):734747. doi:10.1542/peds.2014-2037

50. Christakis DA, Garrison MM, Ebel BE, Wiehe SE, Rivara FP. Pediatric smoking prevention interventions delivered by care providers: a systematic review. Am J Prev Med. 2003;25(4):358-62. doi:10.1016/s0749-3797(03)00214-9 
51. Leventhal H, Cleary PD. The smoking problem: a review of the research and theory in behavioral risk modification. Psychological bulletin, $1980.88(2)$ : p. 370.

52. DiFranza JR, Savageau JA, Fletcher K, O’Laughin J, Pbert L, Ockene JK et al. Symptoms of tobacco dependence after brief intermittent use: the Development and Assessment of Nicotine Dependence in Youth-2 study. Arch Pediatr Adolesc Med. 2007;161(7):704-710. doi:10.1001/archpedi.161.7.704

53. O’Loughlin J, DiFranza J, Tyndale RF, Meshefedjian G, McMillanDavey E, Clarke PBS et al. Nicotine-dependence symptoms are associated with smoking frequency in adolescents. American journal of preventive medicine.2003. 25(3): p. 219-225.

54. Gervais A, O'Loughlin J, Meshefedjian G, Bancej C, Tremblay M. Milestones in the natural course of onset of cigarette use among adolescents. CMAJ. 2006;175(3):255-261. doi:10.1503/cmaj.051235

55. O'Dell LE. A psychobiological framework of the substrates that mediate nicotine use during adolescence. Neuropharmacology. 2009;56 Suppl 1(Suppl 1):263-278. doi:10.1016/j.neuropharm.2008.07.039

56. Garrison MM, Christakis DA, Ebel BE, Wiehe SE, Rivara FP. Smoking cessation interventions for adolescents: a systematic review. Am J Prev Med. 2003;25(4):363-367. doi:10.1016/ s0749-3797(03)00213-7

57. Zhan W, Dierker LC, Rose JS, Selya A, Mermelstein RJ. The natural course of nicotine dependence symptoms among adolescent smokers. Nicotine Tob Res. 2012;14(12):1445-1452. doi:10.1093/ ntr/nts031

58. Aguirre-Molina M, Gorman DM. Community-based approaches for the prevention of alcohol, tobacco, and other drug use. Annu Rev Public Health. 1996;17:337-358. doi:10.1146/annurev. pu.17.050196.002005

59. Bloch P, Toft U, Reinbach HC, et al. Revitalizing the setting approach - supersettings for sustainable impact in community health promotion. Int J Behav Nutr Phys Act. 2014;11:118. Published 2014 Sep 14. doi:10.1186/s12966-014-0118-8

60. Dr Anneke Bühler, Dr Johannes Thrul. Prevention of addictive behaviours. 2015: European Monitoring Centre for Drugs and Drug Addiction, Luxembourg: Publications Office of the European Union, 2015

61. Wakefield MA, Loken B, Hornik RC. Use of mass media campaigns to change health behaviour. Lancet. 2010;376(9748):1261-1271. doi:10.1016/S0140-6736(10)60809-4

62. van den Putte B, Yzer M, Southwell BG, de Bruijn GJ, Willemsen MC. Interpersonal communication as an indirect pathway for the effect of antismoking media content on smoking cessation. J Health Commun. 2011;16(5):470-485. doi:10.1080/10810730.201 0.546487

63. Brinn MP, Carson KV, Esterman AJ, Chang AB, Smith BJ. Mass media interventions for preventing smoking in young people. Cochrane Database Syst Rev. 2010;(11):CD001006. Published 2010 Nov 10. doi:10.1002/14651858.CD001006.pub2

64. Stead M, Angus K, Langley T, Katikireddi SV, Hinds K, Hilton S, Lewis $\mathrm{T}$ et al. Mass media to communicate public health messages in six health topic areas: a systematic review and other reviews of the evidence. Southampton (UK): NIHR Journals Library; 2019 Apr. (Public Health Research, No. 7.8.) Available from: https://www. ncbi.nlm.nih.gov/books/NBK540706/ doi: 10.3310/phr07080
65. Bala MM, Strzeszynski L, Topor-Madry R. Mass media interventions for smoking cessation in adults. Cochrane Database Syst Rev. 2017;11(11):CD004704. Published 2017 Nov 21. doi:10.1002/14651858.CD004704.pub4

66. Carson冈Chahhoud KV, Ameer F, Sayehmiri K, Hnin K, van Agteren JEM, Sayehmiri F, Brinn MP, Esterman AJ, Chang AB, Smith BJ. Mass media interventions for preventing smoking in young people. Cochrane Database of Systematic Reviews 2017, Issue 6. Art. No.: CD001006. DOI: 10.1002/14651858. CD001006.pub3.

67. Goldman LK, Glantz SA. Evaluation of antismoking advertising campaigns. JAMA. 1998;279(10):772-777. doi:10.1001/ jama.279.10.772

68. Hornik RC, Yanovitzky I. Using Theory to Design Evaluations of Communication Campaigns: The Case of the National Youth Anti-Drug Media Campaign. Commun Theory. 2003;13(2):204-224. doi:10.1111/j.1468-2885.2003.tb00289.x

69. Darren M, Hawkins KB, Bredfeldt C, Wolf H, Tercyak KP. The effects of framed messages for engaging adolescents with online smoking prevention interventions, Translational Behavioral Medicine, Volume 7, Issue 2, June 2017, Pages 196-203, https:// doi.org/10.1007/s13142-017-0481-5

70. Prokhorov AV, Kelder SH, Shegog R, Conroy JL, Murray N, Peters R, et al. Project ASPIRE: An Interactive, Multimedia Smoking Prevention and Cessation curriculum for culturally diverse high school students. Subst Use Misuse. 2010;45(6):9831006. doi:10.3109/10826080903038050

71. Hefler M, Liberato SC, Thomas DP. Incentives for preventing smoking in children and adolescents. Cochrane Database Syst Rev. 2017;6(6):CD008645. Published 2017 Jun 6. doi:10.1002/14651858.CD008645.pub3

72. Kok G, Bartholomew LK, Parcel GS, Gottlieb NH, Fernández ME. Finding theory- and evidence-based alternatives to fear appeals: Intervention Mapping. Int J Psychol. 2014;49(2):98107. doi:10.1002/ijop.12001

73. Landman A, Ling PM, Glantz SA. Tobacco industry youth smoking prevention programs: protecting the industry and hurting tobacco control. Am J Public Health. 2002;92(6):917930. doi:10.2105/ajph.92.6.917

74. Michie S, van Stralen MM, West R. The behaviour change wheel: a new method for characterising and designing behaviour change interventions. Implement Sci. 2011;6:42. Published 2011 Apr 23. doi:10.1186/1748-5908-6-42

75. Brotherhood A and Sumnall HR., European drug prevention quality standards: a quick guide. 2013: EMCDDA.

76. Jepson, R.G., Harris, F.M., Platt, S. et al. The effectiveness of interventions to change six health behaviours: a review of reviews. BMC Public Health 10, 538 (2010). https://doi. org/10.1186/1471-2458-10-538

77. Ridde V, Pérez D, Robert E. Using implementation science theories and frameworks in global health BMJ Global Health 2020;5:e002269.

78. EMCDDA, Prevention and Evaluation Resources Kit (PERK). 2010, Luxembourg: Publications Office of the European Union. 